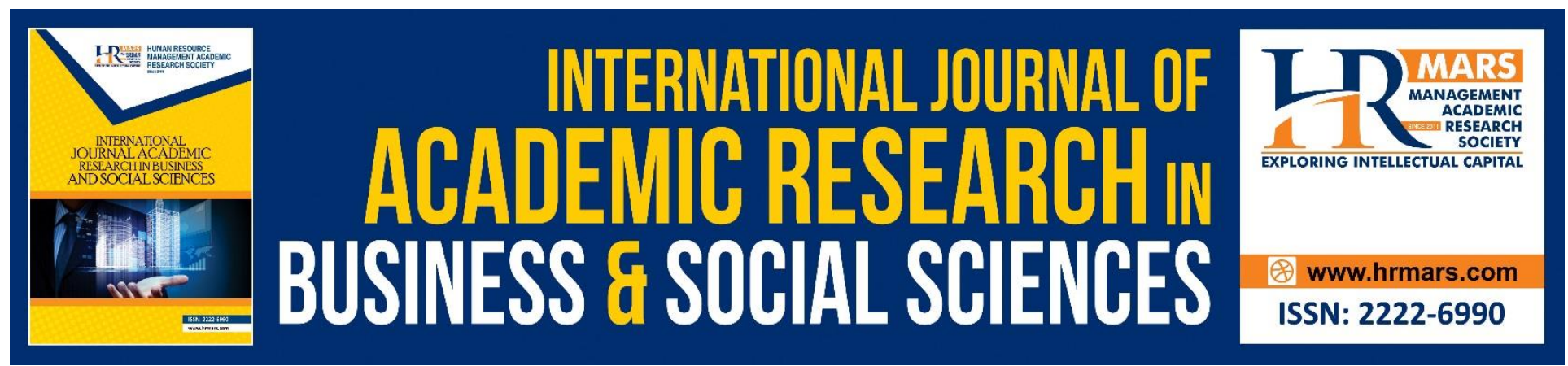

\title{
Implementing the Malaysian Heritage Garden as the Identity for National Landscape: Case Study in Putrajaya
}

Ahmad Zamil Zakaria, Melasutra Md Dali, and Hazreena Hussein

To Link this Article: http://dx.doi.org/10.6007/IJARBSS/v9-i1/5489

DOI: $\quad 10.6007 /$ IJARBSS/v9-i1/5489

Received: 17 Dec 2018, Revised: 11 Jan 2019, Accepted: 27 Jan 2019

Published Online: 08 Feb 2019

In-Text Citation: (Zakaria, Dali, \& Hussein, 2019)

To Cite this Article: Zakaria, A. Z., Dali, M. M., \& Hussein, H. (2019). Implementing the Malaysian Heritage Garden as the Identity for National Landscape: Case Study in Putrajaya. International Journal of Academic Research in Business and Social Sciences, 9(1), 898-914.

Copyright: (C) 2019 The Author(s)

Published by Human Resource Management Academic Research Society (www.hrmars.com)

This article is published under the Creative Commons Attribution (CC BY 4.0) license. Anyone may reproduce, distribute, translate and create derivative works of this article (for both commercial and non-commercial purposes), subject to full attribution to the original publication and authors. The full terms of this license may be seen at: $\underline{\text { http://creativecommons.org/licences/by/4.0/legalcode }}$

Vol. 9, No. 1, 2019, Pg. 898 - 914

Full Terms \& Conditions of access and use can be found at http://hrmars.com/index.php/pages/detail/publication-ethics 


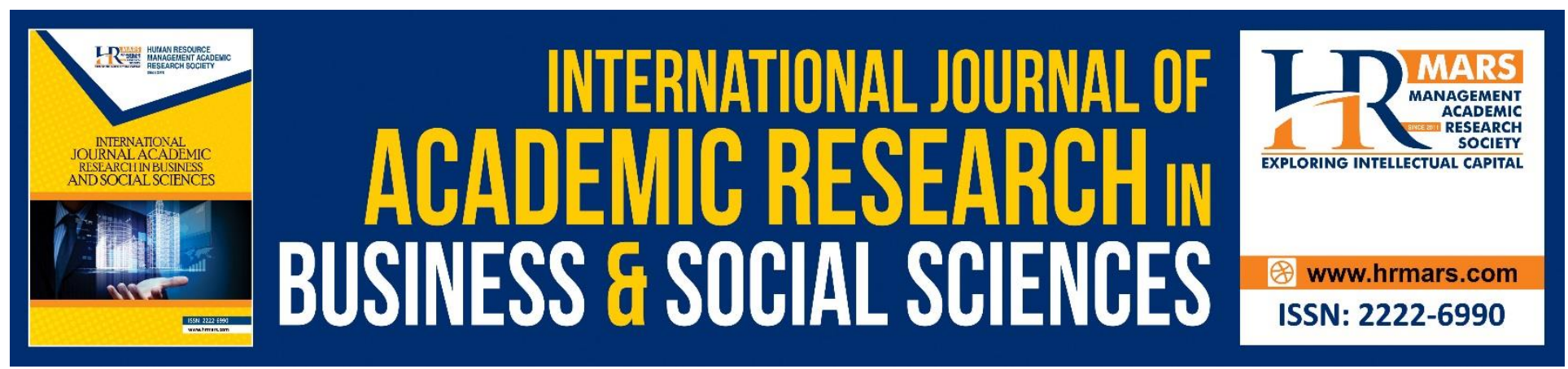

\title{
Implementing the Malaysian Heritage Garden as the Identity for National Landscape: Case Study in Putrajaya
}

\author{
Ahmad Zamil Zakaria ${ }^{1}$, Melasutra Md Dali², and Hazreena \\ Hussein ${ }^{3}$ \\ ${ }^{1}$ Universiti Teknologi MARA Perak Branch, Seri Iskandar Campus, Perak \\ $2 \&{ }^{3}$ Center for Sustainable Urban Planning \& Real Estate, Faculty of Built Environment, \\ University of Malaya, Malaysia
}

\begin{abstract}
Nowadays, there are plentiful open parks operated for relaxation and entertainment in Malaysia. Putrajaya is one of the cities which have many public parks around. The aim of this study was to acquire the opinions of users regarding the needs of establishing "the Malaysian heritage garden concept" today. The main objective is to distinguish the factors that caused the implementation difficulties, and the initiatives that have been made to introduce this concept. Site observation and interview methods are used for collecting data. Respondents were selected using the simple random sampling technique among users of the public parks in Putrajaya and the experts of Malaysian Garden concept. The results revealed that the entire park design does not highlight the elements of the Malaysian Garden concept (the Malay Garden criteria's). From the information gathered can be presumed that Putrajaya is yet not prepared to highlight the traditional elements in landscape design. Although, Putrajaya is the federal administrative center of the country, but still not able to accentuate the national identity.

Keywords: Malaysia Heritage, Malaysian Garden, Malay Garden, National Identity, Putrajaya.
\end{abstract}

\section{Introduction}

Putrajaya is a planned city in Malaysia. It is a smart city that developed by politics. The city is produced to raise the respect of the Malays altogether. Social components give off an impression of being heading to the arrangement of Putrajaya is to make a "livable" city and also charming (Perbadanan Putrajaya, 2018). The impact of the development of Putrajaya, the country has had an "administrative city" that developed on par with the rapid physical development of the country. Most of the buildings that are in the Territory of Putrajaya implement the architecture from abroad. For example, the architecture of the "Putra Mosque" is taken from Persian, while the "Prime Minister's Department Complex" (Putra Perdana) adapted from the Roman 
architecture (New Straits Times, 2018). This issue has affected the design of public parks in the region. The development of public parks is not concerned with the local culture, especially the Malays. Landscape design that sees modern-style and adapts the concepts of famous all over the world cannot help the development of the local landscape design. According to Harun \& Abdullah (2018), a key executed masterplan example is Putrajaya, which was designed as an "intelligent garden city" using the model of the garden city derived from planning concepts of the West.

Currently, there are various design concepts in the field of landscape architecture. Among the favourite landscaping concepts are Japanese, Balinese and English Garden. Through these concepts, the culture of its community been promoted to the outside world (Zakaria et al., 2013a). In Malaysia, the current scenario of landscape focuses on contemporary designs, which means that the Malaysian community does not have the one landscape identity to be proud. The problems that arise from this, researchers have studied the level of concern of Malaysians towards cultural elements that have been applied in the design of public parks in Putrajaya. Promoting an ethnically oriented culture is difficult at present (Zakaria et al., 2014a). Figure 1 shows the map of parks in Putrajaya. Inside the map, we can see the urban parks, wetlands, open spaces, waterfront promenades, boulevards and lakes that make Putrajaya's city planning so beautiful.

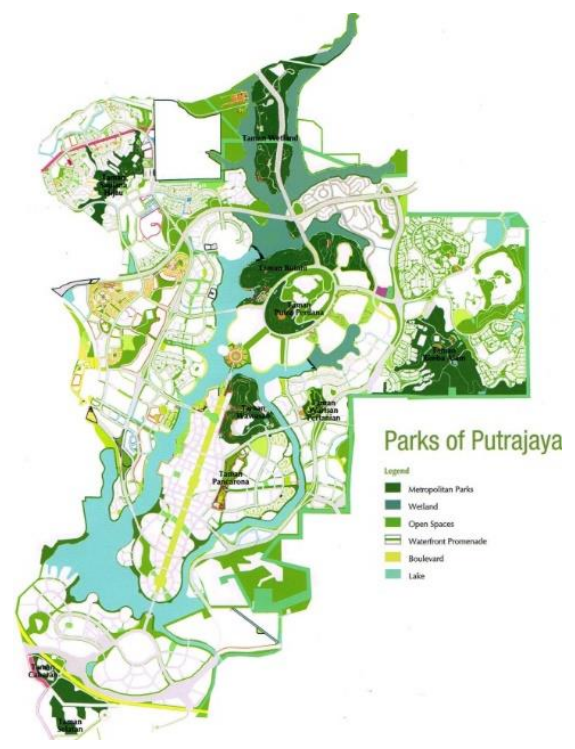

Figure 1. Parks of Putrajaya (Putrajaya Corporation, 2010).

\section{National Identity}

Referring to Dahbour (2002), two concepts of national identity are prevalent in contemporary political philosophy; (i) a strict one that regards nationality as based on a belief in common ancestry or ethnicity and, (ii) a loose one that views nationality as a malleable term without fixed properties. National identity is a sense of a nation as a cohesive whole, as represented by distinctive traditions, culture, and language (Oxford Dictionaries, 2018). The set of qualities and beliefs that make individual or group different from others is another identity definition 
(Merriam-Webster, 2015). Researchers have found that those people have made a strong commitment to an identity tend to be happier and healthier rather than those who have not. Those with a status of identity diffusion tend to feel out of place in the world and do not pursue a sense of identity. Kuean (1999) stated the national identity are tied to a specific social conception of space, built from selected landscape types and individual spatial components. According to Mandler (2006), the ideologies such as patriotism, nationalism and the idea of "national character", which may or may not be incorporated into "identities".

\section{Cultural Landscape}

The cultural landscape is regarded as being of the most complex designs which involve interactions between man, nature, cultural values and the associated built environment (Harun et al., 2017). According to Sumardjo (2000), culture is a system of symbols which rely on the wearer, an organisation symptom (behavioural), objects (woodworking tools and production ideas (beliefs and knowledge) and sentiment (attitudes and values). The cultural identity that relates to a person's heritage helps them to identify with others who have the same traditions and primary belief system - the "community identity" concerning the acknowledgement that cultural landscapes form part of the living memory of past generations and can provide connections to future generations (ICOMOS, 2014). Referring to Lowenthal (1997), a landscape is considered as a common heritage and a collective identity.

\section{Green Spaces}

Givi et al. (2015) said the urban green space is defined as any piece of land covered by vegetation and often referred to as parks, golf courses, sports field and other open spaces within urban builtup area whether publicly accessible or not. Green spaces frequently comprise of all natural and human-made networks of multifunctional ecological systems within, around and between urban and semi-urban green spaces (Tzoulas et al., 2007).

\section{The Malay Traditional Garden in Malaysia}

The Malays had once been civilised, admired by the outside people and it has been depicted in most ancient Malay manuscripts (Zakaria et al., 2014b). The designs of Malay Garden concern for good space layout to create a surrounding of high functionality and benefits towards users. Ismail et al. (2015) said the Malay Garden plays a significant function of sustaining the residents. The planting compositions in the garden indicate not only intrinsic cultural values, such as food, medicine, cosmetic, belief but also decoration and provision of shade. Abu Bakar (2012) agreed that the Malay landscape could be regarded as a complete life, which includes aspects of the divine, natural and human.

\section{The Malaysian Garden Concept}

Among the interests of the Malaysian Garden establishment is; 'Conservation of historical and cultural value, it is to be inherited and cherished by future generations. Besides, it is also an effort to maintain the cultural landscapes' (National Landscape Department, 2009). According to Abu Bakar (2012), a consensus has been reached, where the Malaysian Landscape characteristics must be based on the Malay Landscape concept criteria's, and the National Landscape Department agreed on it in 2007. Application of the Malay Landscape element as identity, in 
design, will be the basis of the construction of the park in Malaysia. The problem here is, after all, is there a concept called the Malay Landscape or Malay Garden?

\section{Materials and Methods}

The methodology for this research includes the formation of objectives, data collection, summary and findings, and last suggestion and conclusion. In this research, researchers did not just use the qualitative method, but quantitative as well, by using questionnaires. The "observation" method using to watch something carefully and accurately record in some way the activities or situation to capture data relevant to the research issues (Gray \& Malins, 2004). Questionnaires have been used "simple random sampling" in choosing respondents and "Semi-Structure In-Depth" technique.

\section{Sample Criteria}

"Criterion Sampling" is the criteria specified by the researcher in the process of obtaining the sample (Creswell, 2007). The sample is selected according to the criteria as follows:

1) Must be a Malay (user's).

2) Using a public park when the study was conducted (user's).

3) Not in the children's category (user's).

4) Members of the Malaysian Garden meeting/seminar organized by the National Landscape Department (NLD) in 2007 (for expert's perception only).

A total of eight (8) public parks around Putrajaya has become a case study. The public parks are:

1) Putrajaya Challenge Park

2) Putrajaya Equestrian Park

3) Putra Perdana Park Putrajaya

4) Agriculture Heritage Park Putrajaya

5) Wawasan Park Putrajaya

6) Wetland Park Putrajaya

7) Putrajaya Botanical Garden

8) Rimba Alam Park Putrajaya 
The selection of public parks chosen by the researchers found it to be the main attraction for visitors, as well as tourists whether for recreational or social visit purposes. It refers to observation studies conducted before the questionnaire was used to respondents.

Every public park has been allocated a total of 20 respondents. The total sample for this study was 160 peoples. The study was conducted for two weeks (14 d), and it was done during the school holidays in 2016 (December). The school holidays are chosen because the researchers found that many people at that time.

The aspects of the criteria that have been queried in the questionnaire (research perceptions) are about the park design, the number of users, the user comfort, the adapting the concept of favourite landscape design, the cultural elements, the modern elements, and the potential to absorb elements of local culture. These criteria have been developed from Zakaria et al. (2013b, 2014b, 2016a, 2016b, 2017) related to the Malay Garden and its elements.

Experts were divided into three categories which are; (a) Academic: Senior Lecturer + previously had a study on the subject [2 persons]; (b) Industry player: consultant + contractor [2 persons]; \& (c) Authorities: decision maker + NLD Director General [1 person]. A total of five (5) respondents were used in this study. For information, the total number of members of the meeting/seminar is 21 (including those who retired and passed away).

\section{Assessing the Opinion of the Users of Public Parks}

According to Turan et al., (2016), satisfaction is one of the most central concepts in the study of recreation behaviour. The view of the users of public parks is indispensable for understanding the rationale of this study. Analysis of data is crucial to enable researchers to elaborate on the current scenario and to ease the making of the recommendation of the "Cultural Ethnic Landscape Elements" and design at the end of the study.

\section{Assessing the Cultural Landscape}

This study has used the Melnick's method, which states the importance to identify the characteristics and elements of nature, culture, and visual interest at a selected place (Melnick 2009). This process and guidelines facilitate the researchers for more focus on the subject matter to increase the validity and reliability of the study.

\section{Assessing the Issues and Problems in Implementing the Malaysian Garden Concept}

The problems are arising from the absence of guidelines for designing the Malay Garden concept. This problem will consequence in the effort to bring the concept of Malaysian Garden to a dead end and resulted from the absence of landscape identities for Malaysia. It has occasioned many parties take advantage, for example, arbitrarily making their designs without thorough research on the theory and philosophy of the Malaysian Garden design. Through past research findings, there is indeed difficulty in producing landscape design model/design guidelines. Researchers namely have outlined some barriers: 
1) Obsessive view of society that is extravagant for their nation

2) Difficulties in obtaining information from figures in landscape architecture, as this type of study are not popular among academics

3) Need to have many respondents to represent each group of stakeholders.

4) The government's attitude in landscape architecture issues, often regard it as trivial (unimportant and insignificant).

\section{Results}

The researchers have conducted on-site observation before any selected public park. After having the perception of the public park, then review the opinion of the user is executed. The researchers have made the ranking, according to the perceptual after a site visit conducted (Refer to Table 1). Researchers are beginning the study through observation methods; the researchers have chosen Putrajaya Botanical Garden and Putra Perdana Park as a public park that has the potential to be highlighted cultural ethnic landscape design (first and second ranks: results from the observation studies have been conducted).

Table 1. The perception of the researchers after conducting visits to the public parks in Putrajaya.

\begin{tabular}{|c|c|c|c|c|c|c|c|c|}
\hline Public Park & $\begin{array}{c}\text { Putrajaya } \\
\text { Challenge } \\
\text { Park }\end{array}$ & $\begin{array}{c}\text { Putrajaya } \\
\text { Equestrian } \\
\text { Park }\end{array}$ & $\begin{array}{c}\text { Putra } \\
\text { Perdana } \\
\text { Park } \\
\text { Putrajaya }\end{array}$ & $\begin{array}{l}\text { Agriculture } \\
\text { Heritage } \\
\text { Park } \\
\text { Putrajaya } \\
\end{array}$ & $\begin{array}{c}\text { Wawasan } \\
\text { Park } \\
\text { Putrajaya }\end{array}$ & $\begin{array}{l}\text { Wetland } \\
\text { Park } \\
\text { Putrajaya }\end{array}$ & $\begin{array}{c}\text { Putrajaya } \\
\text { Botanical } \\
\text { Garden }\end{array}$ & $\begin{array}{c}\text { Rimba } \\
\text { Alam Park } \\
\text { Putrajaya }\end{array}$ \\
\hline Park Design & 4 & 3 & 4 & 4 & 3 & 4 & 5 & 2 \\
\hline $\begin{array}{l}\text { Number of } \\
\text { Users }\end{array}$ & 3 & 2 & 4 & 4 & 2 & 5 & 5 & 2 \\
\hline User Comfort & 4 & 4 & 4 & 4 & 4 & 5 & 5 & 3 \\
\hline $\begin{array}{l}\text { Adapting the } \\
\text { Concept of } \\
\text { Popular } \\
\text { Landscape } \\
\text { Design }\end{array}$ & 2 & 2 & 3 & 2 & 2 & 2 & 3 & 1 \\
\hline $\begin{array}{l}\text { Cultural } \\
\text { Elements }\end{array}$ & 1 & 3 & 3 & 3 & 2 & 3 & 3 & 2 \\
\hline $\begin{array}{l}\text { Modern } \\
\text { Elements }\end{array}$ & 5 & 3 & 5 & 5 & 5 & 5 & 5 & 2 \\
\hline $\begin{array}{l}\text { The Potential } \\
\text { to Absorb } \\
\text { Elements of } \\
\text { Local Culture }\end{array}$ & 3 & 4 & 5 & 5 & 5 & 5 & 5 & 5 \\
\hline Ranking & 6 & 7 & 2 & 4 & 5 & 3 & 1 & 8 \\
\hline
\end{tabular}

The respondents in this study were composed of $39 \%$ men $(n=62)$ and women, $61 \%(n=98)$. The majority $(n=88)$ age of the respondent in this study was between 20 y.o. to 45 y.o. The rest are respondents $(n=72)$ within the age range of 30 y.o. to 35 y.o. The study of perception and opinion of users has answered the question as follows: 
INTERNATIONAL JOURNAL OF ACADEMIC RESEARCH IN BUSINESS AND SOCIAL SCIENCES

Vol. 9, No. 1, Jan, 2019, E-ISSN: 2222-6990 @ 2019 HRMARS

\section{The Landscape Design of Public Parks Users' Choice}

Out of 160 respondents involved in this study, $67 \%(n=107)$ of them chose a modern landscape design. Besides that, $25 \%(n=40)$ of respondents liked it if there is a traditional element in public parks. A total of $8 \%(n=13)$ thought it was good to have a mix of landscape design so that people can know the culture of other nations.

\section{Suitability to Implement Cultural Ethnic Landscape Design in Malaysia}

A total of $55 \%(n=88)$ of the respondents have chosen neutral, which means they are not sure whether the concept of landscape design can be applied in Malaysia. As much as $30 \%(n=48)$ of respondents chose the most suitable for us to develop or promote local culture nowadays. However, there are $5 \%(n=8)$ of the interviewees consider the concept is not appropriate for development at present, as many visitors consist of teenagers.

\section{Suitability to Implement the Design of Cultural Ethnic Landscape in a Public Park (refer to the location of the interview)}

About $65 \%(n=104)$ of respondents said that it is possible and appropriate to implement ethnic, cultural landscape in this park. It is because most visitors consist of Malaysians, especially the Malays. As much as $23 \%(n=37)$ of respondents are not sure whether it can be implemented or not in this park because it is not convinced of the strength of the concept. Only slightly which are $12 \%(n=19)$ of respondents have expressed inappropriately for such a concept to be developed because the existing concept was good enough.

\section{Landscape Elements That Became a Favorite of Respondents in the Park}

Plants (softscape) in this park to be the first choice of visitors. Most visitors love the beautiful and lush plants in the parks. Besides, the visitors chose shelter/gazebo (wakaf) as a critical landscape element and should be in every public park. The landscape design is in third place in the list of elements of the public park user's choice. Some of the visitors feel attractive landscape design can attract the attention of visitors to come again and again. In fourth place, the users of public parks chose the sculpture (hardscape elements). These features will make a public park more unique and artful. The fifth element that became a favourite of public park visitors is a garden lighting system (light). Good lighting can attract visitors to use the park at night.

\section{The Concept of Design That Can Be Adapted to This Park in the Future}

Most of the respondents felt that in the future the park would be more natural with mature trees (large and fertile) and the softscape element will exceed the hardscape. Some respondents felt this park in the next $10 \mathrm{yr}$. to $15 \mathrm{yr}$. will be implemented with a new concept of the landscape (trendy). They were not sure of a landscape concept developed in Malaysia will endure, if compared to other countries such as Japan and Spain. For some respondents, they thought the park would remain with the current concept, due to the cost of construction of a new public park is very high. 
INTERNATIONAL JOURNAL OF ACADEMIC RESEARCH IN BUSINESS AND SOCIAL SCIENCES

Vol. 9, No. 1, Jan, 2019, E-ISSN: 2222-6990 @ 2019 HRMARS

What Be Kinds of Cultural Ethnic Landscape Element Incorporated in the Design of Public Parks in The Future?

Most of the respondents listed the shelter/gazebo (wakaf), garden chairs, gates, fences and water vessel/jars as elements that can be incorporated in public parks in the future. The elements of the landscape garden are referring to elements of the Malays, and this is because all the respondents are comprised of the Malays ethnic. Does this study bias? It is not because from the outset the researchers wanted to explore the Malay cultural elements that can be applied in landscape architecture.

\section{The Importance of Introducing Traditional Elements for The Survival of the Malays Culture}

A total of $86 \%$ ( $n=138)$ of respondents said it is necessary for us to introduce the Malay cultural heritage. However, only a small number of those interviewed, $14 \%(n=22)$, felt the Malay cultural heritage must not be shown in the exhibition. They thought, let's culture retained in place, for example, in the Malay villages. According to the respondents, they believe that culture is a civilised nation and it can be used to benefit the tourism sector. Also, proud of the nation's history is one of the characteristics of people with first-class brains. We can conclude that users of public parks have a good knowledge of landscape design and heritage. The average opinion of the respondents pointed to the improvement and preservation of Malay culture. In the next part of the discussion, the researchers deliberate on how to incorporate the Malay Garden Design Concept to an existing public park. People prefer to implement something trendy and modern. The way of life is seen as the factors influencing their behaviour today. People desire to live in cities than in villages and children nowadays are less exposed to the culture of their parents.

\section{The status of the Malaysian Garden design concept according to an expert}

1) All respondents have stated that the awareness to develop this concept is still less or indirectly concerned, whether at the community level, local authorities, consultants, contractors and ministries.

2) Two (2) out of five (5) respondents stated the need to mix the cultural elements of three (3) major ethnic groups, as it is argued that Malaysian Garden should have shown harmony in the plural society.

3) Three (3) out of five (5) respondents have indicated that industrial players have no good relationship with academics in the field of landscape architecture, and this has created disagreements in the Malaysian Garden concept design (so far, they only follow the concepts and knowledge which is in themselves).

4) Four (4) out of five (5) respondents stated that most landscape designers and landscape architects were not interested in proposing this concept due to lack of knowledge, less publicity, not being called for information sharing activities and lack of knowledge on Malay culture.

5) All respondents agreed with the proposal to create diversity in promotional activities, whether at the national or international level. It should be based on the latest trends (online marketing and viral methods) and conventional methods (there must be evidence of the existence of this concept and has been implemented on a site that can attract public attention). 


\section{Discussion}

In this section, the researchers will touch on some of the relationships between a public park in Malaysia and the Malay Garden Design Concept. This article will also explain to the reader, about the importance of the Malay Garden Design Concept to the field of landscape architecture in Malaysia.

\section{What is the Malay Garden?}

Zakaria et al. (2017) argued the basis of culture could be divided into four parts, artistic, social, economic and political. All four sections are relevant in creating the landscape concept for the Malay community in Malaysia. According to him, three essential things that need to be studied before knowing the identity of the Malay landscape is; product potential, the challenges before it recognised, and methods of globalisation. Refer to figure 3.

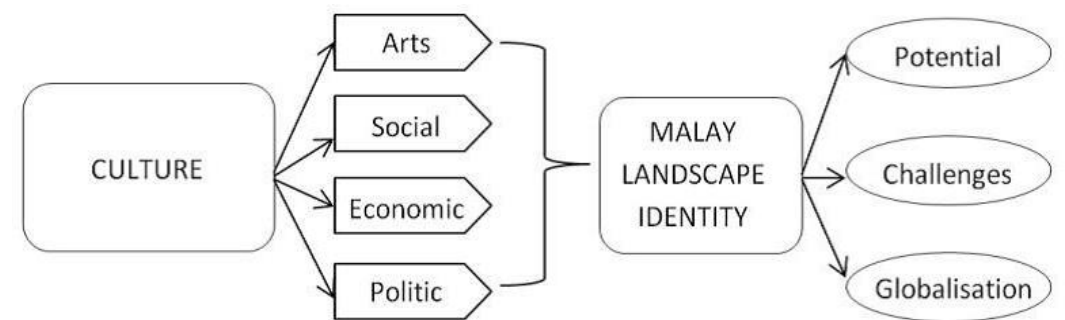

Figure 3. The Culture relationship influencing the uniqueness of Malay Landscape (Zakaria et al., 2017)

Zakaria et al., (2013a) stated, the original compositions of the Malay Garden design are; the design concept and principal components which include softscape elements and hardscape elements. The characteristics of the Malay Garden in the past was emphasised its synchronisation with the house setting (the use of natural materials is core to produce hard landscape). Through research conducted earlier, researchers have identified several potential and constraints on the concept of Malay Garden. The most significant potential is the idea become a legacy for generations and need to be passed down to future generations. The constraints that not able to be handled by the Malay community now is the lack of understanding of this concept. It has made the community less appreciate and prefer another landscape concept. Data has shown, due to the lack of understanding of this concept, it has caused public parks in Putrajaya not convinced to implement it. They fear of their own shadow and belittled.

\section{How to Incorporate the Concept of the Malay Garden into Existing Public Parks?}

All public parks are no problem to introduce the concept of "Malay Garden". For starters, it does not need a large area to design the Malay landscape. However, the philosophy, the elements and layout (hardscape and softscape) should follow the real concept of Malay Garden. The designer cannot be mixed up with the concept with others, nor change the function of a landscape element according to their understanding. Maybe we will be misinterpreted by saying the concept is like a landscape in a traditional Malay village. It is where the creativity of a designer to create a design to be an exciting, unique and uses the basic idea of "Tropical Gardens". From the data obtained, there is an option if this concept is to be implemented. Some visitors suggest that only small spaces need to be allocated 
INTERNATIONAL JOURNAL OF ACADEMIC RESEARCH IN BUSINESS AND SOCIAL SCIENCES

Vol. 9, No. 1, Jan, 2019, E-ISSN: 2222-6990 (C) 2019 HRMARS

to the Malay Garden design, but it is necessary to generate a psychological and understanding impact on visitors.

\section{The Strength of the Concept of "Malay Garden" Compared to Other Landscape Concept}

The strength of the concept of "Malay Garden" can be seen from the philosophy, culture, and lifestyle of the "Malays as a whole". The Malay landscape concept should stress those things because the practice of philosophy and culture will highlight the way of life of the Malay community (Zakaria et al., 2016a). Lots of Malays long-standing theory is still used until today. Undoubtedly another landscape concept also has a variety of philosophies, but the difference is in the religious sense. The Malays in Malaysia are Muslims. Indirectly the philosophies more directed on the teachings of Islam. Malay culture is not the same as other races.

Abu Bakar (2012) said culture and beliefs would be given priority in the conduct certain events and activities. Malay culture in the landscape can be seen from the placement/layout of the hard landscape (hardscape). For example, "tempayan" (water vessel/jars), we often see it placed on the staircase entrance. Nevertheless, it can also be placed at the rear of the house near the toilet or bathroom. However, the water vessel was not placed on the left and right of the house compound. The philosophical basis of hard landscape arrangement is functionality and religion (the cleanliness). Others have described the way of life of the Malays as weak people, idlers, and polluter.

That presumption is wrong. The Malays are Muslims, and Islam does not like dirt and laziness. The Malays are said to be less advanced today and inhabit the traditional village does not mean lazy and polluter. Such perceptions should be removed, and the community itself must change themselves. The Malay landscape perhaps will not be gone if the community, tranquillity obeys to the philosophy of Islam that stresses cleanliness in daily life (Zakaria et al., 2016b)

From surveys conducted by researchers, there are park visitors who feel it is not appropriate if we continuously promote foreign countries by presenting their landscape concepts. They argue that our country needs something that can represent the philosophy, identity and dignity of the nation. If referring to the results of previous studies (as described above), then we can feel that this concept has been around, but unfortunately not taken it seriously.

\section{Is the Concept of the "Malaysian Garden" Has Existed?}

The director of the National Landscape Department (NLP) had expressed a desire to produce a concept "Malaysian Garden" (Ismail, 1997). The concept uses the idea of "tropical rainforest" as the subject matter. It was reported $20 \mathrm{yr}$. ago, and maybe some of us are already forgotten the matter. That means the study of "Malaysian Garden" concept does not take a short and quick to produce. It is complicated to be realised on factors such as Malaysia's multiracial society (3 main races are the Malays, Chinese and Indians). Refer to Figure 4. The Chinese and Indians have a strong landscape concept was taken from their home country. However, the problem for the majority, namely Malays who do not have a strong landscape concept for equally paired in a park. 
That is the reason why we need to produce a first the "Malay Garden Design Concept", before aspiring to create the concept of "Malaysian Garden". According to Mr LAr. Ng Sek San in 2007 (well-known landscape architect in Malaysia), the formation of "Malaysian Garden" will take another 100 years and it does not require any coercion to take more than that (Yusof \& Sharuddin, 2013). The answer to this question is "NO", and there has never been a landscape concept like this in Malaysia. Refer to figure 4; it will enable us to understand the concept of Malaysian Garden concept that will be implemented.

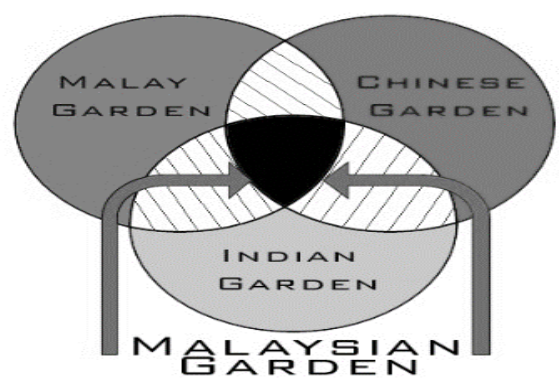

Figure 4: The clash of culture and combination of uniqueness will create the concept of "Malaysian Garden" (Author, 2018)

From the data obtained, it is not easy to claim that the design is "Malaysian Garden". Due to a lack of understanding and awareness among Malaysians especially the parties responsible for developing the landscape industry.

\section{What is the Relationship Between the Study of Malay Garden Design Concept with the Federal Territory of Putrajaya?}

Putrajaya has no personality of its own. It is because the architecture has influenced by outside architecture, so in other words, it has a personality problem. Although there are some drawbacks, it is not too obvious where the adoption of elements of "Responsive Environment" by Bently et al. (1985) has managed to create an atmosphere of harmony and comfort to the public. The recreation park features a unique design, as well as using the selected material causing "sight-seeing" activities, as well as tourism activities that involve the local community as well as from abroad.

The researchers believe the need to the concept of "Malay Garden" applied in the development of a public park in Putrajaya. Local authorities should be more focused on the agenda of the nation, it needs to begin by introducing the Malay identity, as the majority population, and origin ethnic in Malaysia. The difficulty to understand the basis of landscape architecture will be a significant barrier to the public to understand some more complex elements or subject, which deals with the issue of the identity of landscape architecture (Abu Bakar, 2012).

From the researcher's findings, Putrajaya is a place where everyone is visiting Kuala Lumpur. Being strategically located in the middle between KLIA Airport and the capital (Kuala Lumpur) makes it a must-visit place. It has many public parks and beautiful landscapes almost all over the place, has made it a tourist attraction, but unfortunately, visitors will be more served with foreign elements. 


\section{Conclusion}

People are always fascinating to see gardens from around the world. Some have asked researchers why not trying to highlight the concept of "Malaysian Garden", whereas it represents all Malaysians. The correct answer is the concept of Malaysia Garden is not suitable realised at present. From the survey conducted, the lack of activity promoting the culture of the nation (especially Malay culture) is the reason why "cultural ethnic landscape" is complicated to accept today. Two factors, namely, Malaysia is a multiracial country, and the selection of Malay concept that has yet to establish the park will reduce the traditional values to be applied. Although the concept of Malay garden is not an option at this point, as Malaysians, researchers would like to suggest that the research and production of appropriate guidelines should be accelerated.

The role of every member of society is crucial to make it comparable to popular concepts that have become a trend today. Without the cooperation of all parties, any program organised either from the ministry, government departments, local authorities or otherwise will not be welcome. Malaysians need to enjoy it because they already have a landscape design concept that can be proud of the nation. We cannot deny that various programs have been set up to introduce the Malaysian Garden to local and foreign communities. The question here is whether it impacts the Malaysian Garden concept? Is the organisation of significant events such as The Malaysia International Landscape and Garden Festival, FLORIA (The Royal Putrajaya Flower and Garden Festival), KLOBS (Kuala Lumpur Orchid and Bonsai Show), and other state-level events have successfully promoted the concept of Malaysia Garden? Will participation in competitions and exhibitions internationally ensure that the outside community understands the true Malaysian Garden concept?

According to Marques et al., (2018), as human identity is regarded as an extension of the land, the restoration and maintenance of landscapes and ecosystems often require the active collaboration of local communities in their planning, management, and sustainable development. Putrajaya which was developed with the idea of "Gardens in the City" some called "Intelligent Garden City", has combined the characteristics of a well-planned layout and urban design appropriate to the climate, topography and local culture. However, in the aspect of landscape architecture, it is less successful in applying the concept of local culture, especially the majority, that is Malay. Local authorities need to consider the development of the landscape with the identity of the Malays. It is consistent with the desires of the community who feel the need to promote national identity to outsiders. To date, the use of traditional Malay elements in landscape design in Putrajaya is inferior. There is no doubt that there is little, but its use is not dominant and has little impact on highlighting the Malay Garden concept.

Now, Putrajaya is a must-visit tourist destination when visiting Malaysia. According to the Minister of Urban Wellbeing, Housing and Local Government, the Malaysian government will build more public parks with a target of 67200 ha across the country by 2020 (Utusan Malaysia, 2015). Therefore, this is the potential for introducing the concept of Malay Garden Design via public gardens to be developed in the future. 
INTERNATIONAL JOURNAL OF ACADEMIC RESEARCH IN BUSINESS AND SOCIAL SCIENCES

Vol. 9, No. 1, Jan, 2019, E-ISSN: 2222-6990 (C) 2019 HRMARS

\section{Acknowledgements}

We would like to express our gratitude to the Center for Sustainable Urban Planning \& Real Estate, Faculty of Built Environment, University of Malaya (SUPRE), the Centre for Knowledge and Understanding of Tropical Architecture and Interior (KUTAI) and Taman Alam Melayu Nusantara (T.A.M.A.N) UiTM Perak Branch for the precious support during the research period.

\section{Corresponding Author}

Ahmad Zamil Zakaria, Universiti Teknologi MARA Perak Branch, Seri Iskandar Campus, Perak, Malaysia (Email: zamil227@perak.uitm.edu.my)

\section{References}

Abu Bakar, J. (2012), Taman Malaysia Ke Arah Identiti Nasional (Malaysian Garden Towards a National Identity), Penerbit UTM Press, Malaysia, pp. 7. http://penerbit.utm.my/books-catalog/

Bently, I., Alcock, A., Murrain, P., McGlynn, S., and Smith, G. (1985), Responsive environments: A manual for designers, Architectural Press, UK. https://nexosarquisucr.files.wordpress.com/2016/05/responsive environments by ian bentley et - al.pdf

Creswell, J. (2007), Qualitative Inquiry and Research Design; Choosing Among Five Traditions, Sage Publication Inc., London, pp. 127. https://www.amazon.com/Qualitative-Inquiry-Research-DesignTraditions/dp/0761901434

Dahbour, O. (2002), National Identity: An Argument for the Strict Definition, Public Affairs Quarterly, Vol. 16, No. 1, pp. 17-37. https://www.jstor.org/stable/40441311

Givi, A. A., Karimi, S., Foroughi, N., Moarab, Y., and Nikzad, V. (2015), Using Fuzzy Logic Analysis in GIS and FAHP Method for Parks Site Selection in Urban Environment (Case Study: Region 7, Tehran Municipality), Current World Environment, $10(2)$ : pp. 432-444. http://www.cwejournal.org/vol10no2/using-fuzzy-logic-analysis-in-gis-and-fahp-method-for-parkssite-selection-in-urban-environment-case-study-region-7-tehran-municipality/

Gray, C. and Malins, J. (2004) Visualizing research: a guide to the research process in art and design, Ashgate Publishing Limited, UK. http://www.upv.es/laboluz/master/seminario/textos/Visualizing Research.pdf

Harun, N.Z., and Abdullah, A. (2018) Tropical Urbanism: Greenery and Walkways in Mediating Identities. In: Jahn Kassim S., Mohd Nawawi N., Ibrahim M. (eds) Modernity, Nation and UrbanArchitectural Form. Palgrave Macmillan, Cham https://link.springer.com/chapter/10.1007/978-3$\underline{319-66131-5 \quad 6}$ 
INTERNATIONAL JOURNAL OF ACADEMIC RESEARCH IN BUSINESS AND SOCIAL SCIENCES Vol. 9, No. 1, Jan, 2019, E-ISSN: 2222-6990 ㄷ 2019 HRMARS

Harun, N.Z., Mohd Ariffin, N.A., and Abdullah, F. (2017), Changes and Threats in The Preservation Of The Traditional Malay Landscape, Planning Malaysia Journal, Vol. 15, Issue 4, pp. 69 -78. http://www.planningmalaysia.org/index.php/pmj/article/view/318

ICOMOS (2014), The Florence Declaration on Heritage and Landscape as Human Values: Florence, Italy, Retrieved from https://www.icomos.org/images/DOCUMENTS/Secretariat/2015/GA 2014 results/GA2014 Sympo sium FlorenceDeclaration EN final 20150318.pdf

Ismail, F. (1997) Designing the Malaysian Garden, New Straits Times, published on 21 March 1997. http://library.perdana.org.my/Digital Content/Prominent Leaders/Mahathir/News 19682004/1996-1998/1997aj/designing\%20the\%20malaysian\%20garden.pdf

Ismail, N.A., Utaberta, N., Mohd Yunos, M.Y., and Ismail, S. (2015), A Cultural Responsive Landscape Study on Perak Malay Garden: An Expressional Value, Advances in Environmental Biology-AENSI Journals, 9(5): pp. 485-490. http://www.aensiweb.net/AENSIWEB/aeb/aeb/2015/April/485-490.pdf

Kuèan, A. (1999), Cultural Landscapes as Symbols of National Identity-Protection or Change?, Agriculturae Conspectus Scientificus, Vol. 64, No. 4, pp. 259-268. https://studyres.com/doc/6541738/cultural-landscapes-as-symbols-of-national-identity

Lowenthal, D. (1997), European landscape transformations: the rural residue. In P. Groth, \& T.W. Bressi (Eds.) Understanding Ordinary Landscapes (pp.180-188). New Haven, CT: Yale University Press. https://yalebooks.yale.edu/book/9780300072037/understanding-ordinary-landscapes

Mandler, P. (2006), What Is "National Identity"? Definitions and Applications in Modern British Historiography. Modern Intellectual History, 3, pp. 271-297. https://www.cambridge.org/core/journals/modern-intellectual-history/article/what-is-nationalidentity-definitions-and-applications-in-modern-britishhistoriography/D306226150CCA0BC9AEE93F4B405E892

Marques, B., Grabasch, G., and McIntosh, J. (2018), Fostering Landscape Identity Through Participatory Design with Indigenous Cultures of Australia and Aotearoa/New Zealand, Space and Culture, pp. 1-16. https://journals.sagepub.com/doi/abs/10.1177/1206331218783939

Melnick, R.Z. (2009), Climate Change and Landscape Preservation: A Twenty-First-Century Conundrum, APT Bulletin: Journal Of Preservation Technology / 40:3-4 2009 pp. 35-42. http://www.apti.org/apti/clientuploads/pdf/Melnick-40-3-4.pdf

Merriam-Webster. (2015), Identity, Retrieved from https://www.merriamwebster.com/dictionary/identity 
INTERNATIONAL JOURNAL OF ACADEMIC RESEARCH IN BUSINESS AND SOCIAL SCIENCES Vol. 9, No. 1, Jan, 2019, E-ISSN: 2222-6990 (C) 2019 HRMARS

National Landscape Department (2009) Taman Malaysia untuk diwarisi, Kementerian Perumahan dan Kerajaan Tempatan, Malaysia. https://books.google.com.my/books/about/Taman Malaysia untuk diwarisi.html?id=EZyOAQAAC AAJ\&redir esc $=y$

New Straits Times (2018, February), Beautiful architecture enhances city, Retrieved from https://www.nst.com.my/property/2018/02/330925/beautiful-architecture-enhances-city

Oxford Dictionaries. (2018), National Identity, Retrieved from https://en.oxforddictionaries.com/definition/national identity

Perbadanan Putrajaya (2018, December 2018), Background of Putrajaya, Retrieved from http://www.ppj.gov.my/portal/page?_pageid=311,1\& dad=portal\& schema=PORTAL\#1208

Putrajaya Corporation. (2010), Parks of Putrajaya: A Living Heritage, Putrajaya Corporation, Malaysia, pp. 32. http://perpustakaan.krbogor.lipi.go.id/buku/index.php?p=show detail\&id=2066

Sumardjo. J, (2000) Filsafat Seni, ITB, Bandung, Indonesia, pp. 325. https://www.goodreads.com/book/show/2009347.Filsafat Seni

Turan, S.O., Pulatkan, M., Beyazl, D., and Özen, B.S. (2016) User Evaluation of the Urban Park Design Implementation with Participatory Approach Process, Procedia - Social and Behavioral Sciences 216: pp. $\quad 306-315 . \quad$ https://ac.els-cdn.com/S1877042815062229/1-s2.0-S1877042815062229main.pdf? tid=472fba9a-ae75-4ff4-ad41e5d5f648468f\&acdnat=1544985099 4fb95700231e2a43a9e9fec0db482716

Tzoulas, K., Korpela, K., Venn, S., Yli-Pelkonen, V., Kazmierczak, A., Niemela, J., and James, P. (2007), Promoting Ecosystem and Human Health in Urban Areas Using Green Infrastructure: A Literature Review, Landscape and Urban Planning, 81(3): pp. 167-178. http://www.sciencedirect.com/science/article/pii/S0169204607000503

Utusan Malaysia (March, 2015), Lebih Banyak Taman Awam Menjelang 2020, Retrieved from http://www.utusan.com.my/berita/wilayah/kl-putrajaya/lebih-banyak-taman-awam-menjelang$\underline{2020-1.66870}$

Yusof, N. and Sharuddin, S. (2013), Mencari Identiti Taman Malaysia (Searching for Malaysian Garden Identity), Kolej Komuniti Jempol, Kementerian Pedidikan Malaysia. (2013) pp. 25 http://www.kkjns.edu.my/v5/attachments/article/127/Mencari\%20Identiti\%20Taman\%20Malaysia .pdf 
INTERNATIONAL JOURNAL OF ACADEMIC RESEARCH IN BUSINESS AND SOCIAL SCIENCES Vol. 9, No. 1, Jan, 2019, E-ISSN: 2222-6990 (C) 2019 HRMARS

Zakaria, A. Z., Abd. Rashid, M.S. \& Ahmad, S. (2017) Hardscape and Softscape Elements of a Malay Garden, Journal of Social Sciences \& Humanities, JSSH Vol. 25 (S) pp. $109-118$. http://www.pertanika.upm.edu.my/Pertanika\%20PAPERS/JSSH\%20Vol.\%2025\%20(S)\%20Feb.\%202 017/12\%20JSSH(S)-0351-2016-4thProof.pdf

Zakaria, A. Z., Abd. Rashid, M.S., and Ahmad, S. (2016a), The Perak Malay Landscape Furniture Design: An Overview, Proceedings of the 2nd International Colloquium of Art and Design Education Research (i-CADER 2015), Langkawi Island, Kedah Darul Aman, Malaysia, Springer, 2016 edition (23 March 2016), ISBN: 978-981-10-0235-9, pp. 497-510. https://link.springer.com/chapter/10.1007/978-981$\underline{10-0237-3 \quad 49}$

Zakaria, A. Z., Ahmad, A., and Abd. Rashid, M.S. (2016b), The Importance of Soft and Hard Landscape Elements to the Malays Sub-Ethnic in Perak, Procedia-Social and Behavioral Sciences 234: pp. 228$238 . \quad$ https://ac.els-cdn.com/S1877042816314926/1-s2.0-S1877042816314926main.pdf? tid=ca6a395a-d43d-11e7-95d2-

$\underline{00000 a a c b 35 f \& a c d n a t=1511874931 \quad 2 d 4 e e 1 b 1 a a 6 e 3 a 5644 e a e 9 e b e 458 b e 1 e}$

Zakaria, A.Z., Salleh, I.H., and Abd. Rashid, M.S. (2013a), "The Malay Garden Design Concept Opportunity to Be Developed as The Tourism Product", Book Chapter: Hospitality and Tourism Synergizing Creativity and Innovation in Research, CRC Press, ISBN 9781138001510. https://www.taylorfrancis.com/books/9781315798233

Zakaria, A.Z., Salleh, I.H., and Abd. Rashid, M.S. (2013b), Landscape Furniture Present in the Ancient Malay Garden According to Old Manuscripts and Their Effects on the Formation of Malay Garden Design Concept Model in Malaysia, Procedia-Social and Behavioral Sciences, Elsevier, 91: pp. 28-35. http://www.sciencedirect.com/science/article/pii/S1877042813025287

Zakaria, A.Z., Salleh, I.H., Harun, S.N., and Abd. Rashid, M.S. (2014a), "Preservation Characteristics of Malay Garden: A Catalyst for Sustainable Cultural Landscape in Malaysia", Springer; 2014 edition (May 14, 2015), ISBN-13: 978-9812873316 ISBN-10: 9812873317 Edition: 2014th. https://link.springer.com/chapter/10.1007/978-981-287-332-3 28

Zakaria, A.Z., Salleh, I.H., and Abd. Rashid, M.S. (2014b), Malay Landscape Elements as Depicted in the Old Malay Films, Jurnal Pengajian Melayu, Jilid 24. 2013/2014: pp. 1-18. https://ejournal.um.edu.my/index.php/JPM/article/download/9627/6789/ 